\title{
Knowledge is power
}

The idea is as old as democracy itself. In order to make the best possible decision about the future of society, all of its members should know all the details about the issues that are in question. Armed with the relevant knowledge, individuals are most likely to balance alternatives in a rational way and eventually make decisions about how society as a whole should set its standards and react to the challenges of a changing world.

Of course, such a demand is utopian in our modern democracies. Our societies and the world surrounding them have grown larger and more complex since the early days of democracy in ancient Athens. Furthermore, with modern transportation, communication and technology, the world has become more interconnected, so that decisions made in one country are likely to affect others as well. As a consequence, the ideal that everybody should know everything about everything has been relinquished. Today, we elect our government and we trust our representatives to know what they should know and to make the best decisions for us, and we do not give further thought to most issues. Many Americans, for instance, trust their administration to act in their best interest when it decides to go ahead with erecting a shield against nuclear missiles. Most Europeans will certainly not know about the intricacies of Middle-East politics and have no strong opinions on whether the EU engages itself in the peace process or not.

But sometimes there are decisions to be made and topics to be discussed that touch on the basic moral standards that society has set for itself. And it is then that people feel they should be involved in the debate. Indeed, to ignore the public can cause a disastrous loss of trust, not only in the elected representatives, but also in the agencies that we expect to regulate our affairs. The widespread resistance against genetically modified organisms in the food supply is a good example of how public opinion can turn sour if its members are not involved in the decisionmaking process. Indeed, when biotechnology companies and regulating agencies developed and approved GM food, they did not fully appreciate that most consumers are very concerned about what they eat, and that the manipulation of food is a matter of common interest.

Claire Marris's article ('The public views on GMOs: deconstructing the myths', this issue) shows that it is not a lack of knowledge that leads to public mistrust, but rather the decision to push GMOs onto the market without keeping consumers involved and informed. Her research also shows that such decisions can have consequences that go far beyond the original problem, once trust in governmental agencies is lost.

The case of GMOs is not an isolated example. Science is generating more and more knowledge with ever increasing speed. New technologies and new products are being created on the basis of this knowledge, and are rapidly changing the world we live in and the way we live. It should not come as a surprise that the public is often suspicious of new technologies and of those who try to sell them. For science, particularly the life sciences, public perception and public relations have become of prime importance, and the public increasingly demands to be involved in decision-making processes. Thus, it has become important for scientists to find out about the public's perception of science.

Naturally, it is not easy to find out what society at large thinks about a particular topic, especially if it involves a high level of detailed knowledge. Here, Switzerland set a positive example in 1998. Threatened by a referendum on genetic research asking for a ban on transgenic animals, release of transgenic crops and the prevention of patenting innovations in biotechnology, the Swiss Government and Swiss scientists set out to explain to the people the advantages of genetic research. It became the most intense campaign the country had ever seen. For more than two years, the media's extensive coverage resulted in a marked increase in public understanding and acceptance of biotechnology. On June 7, 1998, the Swiss people rejected the referendum with a 2:1 majority.

Another notable example is currently unfolding in Germany. The question whether Parliament should allow the use of surplus IVF embryos for biomedical research is indeed touching on basic standards set by German society. The issue has occupied lawmakers, scientists, humanists and a large proportion of the public, and has instigated a broad debate about ethical principles and the future of biomedical research. ('They are moving', page 552, this issue). Particularly in light of Germany's past, a decision to use embryos_-defined by German law as living beings - to obtain stem cells must be supported by the majority of the population, and only after extensive debate. It seems that German lawmakers, scientists and journalists have learned from the Swiss and the GMO debate that they cannot exclude the public from the decisionmaking process without the risk of facing its wrath later. This is good news for scientists too. Although it at first appears to be a slow and gruelling process, it will most likely better inform the public about the benefits of science and technology. And public support of science has become an important requirement for researchers today.

\section{Holger Breithaupt}

DOI: 10.1093/embo-reports/kve148 